\title{
Migrant Workers in Malaysia: COVID-19's Impact on the Rights of their Children and Siblings in Pakistan
}

\author{
Abdullah Khoso \\ PhD; Sociology and Cultural Studies, Faculty of Arts and Social Sciences, \\ Universiti Malaya, Kuala Lumpur, Malaysia \\ abdullahkhoso@hotmail.com \\ Ahmad Hilmi Mohamad Noor \\ PhD Student, Southeast Asian Studies, Faculty of Arts and Social Sciences, \\ Universiti Malaya, Kuala Lumpur, Malaysia \\ albakry@um.edu.my
}

\begin{abstract}
With the help of narratives of migrant workers in Kuala Lumpur, Malaysia, this article seeks to understands the impacts of the CoviD-19 (known as the 2019 novel coronavirus) pandemic on the rights of their children and children's siblings in Pakistan. The pandemic impacted the flow of remittances to their families, which further impacted children's right to education, livelihoods and food. They also revealed that the pandemic had impacted their children's right to protection, play and development. Children had lost the freedom to play and go outside, socialise and learn. Migrant workers' children and siblings with limited financial support should have been provided with adequate financial and social security support by Pakistan, but they were not. They also revealed that during the pandemic, children were also regular victims of harsh treatment and physical abuse by adult family members, reflecting the exacerbation of issues of breaches of their fundamental right to protection and emotional integrity.
\end{abstract}

\section{Keywords}

COVID-19 - UNCRC - migrant workers' children - right to education - right to play right to non-discrimination 
March 2019 marked the emergence of the CoviD-19 pandemic in China, which henceforth changed the way of living, working, relationships, economies, needs and rights of the global population. Its severe effect on migrant workers is reflected in both developing and developed economies where emerging studies have depicted its impact on the mental health and well-being of said population (Choudhari, 2020; Mukumbang et al., 2020; Suresh et al., 2020). Furthermore, the pandemic has led to a crisis of child rights (Silverman et al., 202O) and the mushrooming of scholarly works delineating the varying dimensions of the impacts on children (Wang et al., 2020; Cahapay, 2020; Raman et al., 2020).

However, scholars have yet to pay more attention to the impacts of the COVID-19 pandemic on the rights to education, protection and other rights of migrant workers' children, who are left in their home countries while their parents are working outside of the country. Generally, their education and other basic needs are dependent upon the resources sent home ("the remittance"') and fatherly and motherly affection and contact displayed through regular social media calls, messages and gifts (Khoso et al., 2020; Wise and Velayutham, 2017; Parreñas, 2001). In particular, the money sent home to families plays a significant role in the lives of migrant workers, encompassing the well-being and home economy of their families. However, the pandemic has reduced the flow of this financial support to families at home, caused a depletion of savings, and resulted in social and economic crises in the lives of these workers and people reliant on them back in their home countries (Karim et al., 202O; Honorati et al., 202O). This remittance reduction is rooted in the loss of employment or low migrant workers' wages in light of COVID-19 (Takenaka et al., 202O).

Past evidence has depicted the benefits of remittance on the child population and their enjoyment of human rights, enabling them to get a better education, have access to health services (Article 25 UNCRC), and better nutrition (Coronel and Unterreiner, 2007; Anderson and Kroeger, 2011). Furthermore, the money ensures a higher amount for health expenses, decreased malnutrition and child mortality rates, and more school enrolment in public and private schools and school completion rates. The reduced amount of money affects children's right to development, right to access health care and the right to quality education as established in Articles 6, 25, 28 and 29 of the UNCRC respectively (United Nations, 1989). Meanwhile, Azizi (2018) has indicated that the remittance reduced female labour participation rates without affecting the male labour force participation rates, which indicates that women might have more time to take care of their children. As the covid-19 pandemic has 
resulted in a decreased flow of remittance reported, questions have arisen regarding the effect of this on migrant workers' families including children's rights.

There is a need to understand whether the current reduced flow of remittance has affected children's rights to education, protection and overall well-being. One may question which children-specific activities/expenses are being cut as a result, as well as the reasoning behind its selection and the specific group of children adversely affected by this reduction. This will be explored in the current article while further assessing other impacts beyond the reduced remittance, for example about the impact of the absence of emotional care and protection of fathers and brothers for their children and siblings from a long distance. Similarly, questions regarding the overall rights of migrant workers' children have emerged during the time their fathers and brothers are affected in a destination country. This article explores the qualitative narratives of Pakistani migrant workers in Kuala Lumpur, Malaysia, in a bid to answer the above questions.

\section{Methods and Respondent's Profile}

The data generated in this study was gathered through six, semi-structured interviews carried out with selected Pakistani migrant workers in Kuala Lumpur, Malaysia, where five of the respondents were undocumented. The interviewer used an interview guide during the interview and probed the migrant workers when and where was necessary.

Typically, the number of married Pakistani migrant workers in Malaysia is low due to most coming to the country when they are young and before they are married. Due to lockdown and movement restrictions enforced by the Government of Malaysia (GoM), three respondents were interviewed through WhatsApp calls as they had moved away from Kuala Lumpur. The other respondents were interviewed in-person at their respective residences, via face-to-face interviews lasting for at least 30 minutes.

The six participants in this study are among thousands of Pakistani migrant workers currently in Malaysia (please see Table 1 for more details of the participants). In 2015, around 70,000 of them were reported in Malaysia (Khoso et al., 2020), whereas no figure was available regarding their numbers in Kuala Lumpur city. However, the combination of the CoviD-19 pandemic, efforts of the GoM to crack down, arrest and deport undocumented migrant workers, and the inhuman and degrading conditions in local detention centres as reported in the media have caused/pushed thousands of them, Pakistanis included, to leave the country (Lee, 2020). 
TABLE 1 Respondent's profile

\begin{tabular}{|c|c|c|c|c|c|c|}
\hline $\begin{array}{l}\text { Name, } \\
\text { age }\end{array}$ & Education & $\begin{array}{l}\text { Marriage } \\
\text { status }\end{array}$ & $\begin{array}{l}\text { Children in } \\
\text { Pakistan, age } \\
\text { (years old) }\end{array}$ & $\begin{array}{l}\text { School- } \\
\text { going } \\
\text { siblings in } \\
\text { Pakistan, } \\
\text { age (years } \\
\text { old) }\end{array}$ & $\begin{array}{c}\text { Year of } \\
\text { entry in } \\
\text { Malaysia }\end{array}$ & $\begin{array}{l}\text { Work } \\
\text { permit }\end{array}$ \\
\hline Sajid, 38 & $\begin{array}{l}\text { Primary } \\
\text { school }\end{array}$ & Yes & $\begin{array}{l}\text { - daughter, } 12 \\
\text { - son, } 6 \\
\text { - son, } 5\end{array}$ & $\begin{array}{l}\text { - brother, } 15 \\
\text { - sister, } 13\end{array}$ & 2017 & No \\
\hline Ayoub, 41 & $\begin{array}{l}\text { Primary } \\
\text { school }\end{array}$ & Yes & $\begin{array}{l}\text { - daughter, } 7 \\
\text { - son, } 3\end{array}$ & - no & 2007 & No \\
\hline $\begin{array}{l}\text { Ashfaq, } \\
43\end{array}$ & $\begin{array}{l}\text { Primary } \\
\text { school }\end{array}$ & Yes & $\begin{array}{l}\text { - son, } 12 \\
\text { - daughter, } 10 \\
\text { - son, } 8\end{array}$ & - no & 2011 & No \\
\hline $\begin{array}{l}\text { Ahmed, } \\
41\end{array}$ & Matriculation & Yes & $\begin{array}{l}\text { - son, } 10 \\
\text { - daughter, } 8 \\
\text { - son, } 3\end{array}$ & $\begin{array}{l}\text { - brother, } 15 \\
\text { - sister, } 13\end{array}$ & 2017 & Yes \\
\hline $\begin{array}{l}\text { Rehmat, } \\
46\end{array}$ & $\begin{array}{l}\text { Primary } \\
\text { school }\end{array}$ & Yes & $\begin{array}{l}\text { - son, } 11 \\
\text { - daughter, } 9 \\
\text { - son, } 7\end{array}$ & - no & 2015 & No \\
\hline Ikram, 28 & Matriculation & No & - No & $\begin{array}{l}\text { - brother, } 14 \\
\text { - sister, } 13\end{array}$ & 2014 & No \\
\hline
\end{tabular}

Among all six respondents, Rehmat, 46, was the oldest and possessed primary school-level education (i.e. dropped out of school after passing the fifth grade). He came to Malaysia in 2015 from Karachi and had three children. Ahmed Ali came to Malaysia in 2011 from Math Chatha village in the Hafizabad district and only went back to Pakistan once when his father died. Married in 2008, he had three children and no siblings of school-going age. Muhammad Ayoub hailed from Ghulam Shah village in the Wahari district and came to Malaysia in 2007. After his marriage in 2009, he had only visited Pakistan twice. Meanwhile, Ahmed Iftikhar held a primary school-level education (i.e. dropped out after fifth grade) and came to Malaysia in 2017 from Gujranwala. His wife and three children lived with his father's family which included Ahmed's three brothers and one sister. The fifth respondent, Sajid Abbasi, was from Dheerkot village in the Rawalpindi district and came to Malaysia in 2017 for financial reasons. When he left, he had three children; they lived with 
his mother and younger brother in the rural part of the district. Sajid stopped his education after matriculation as his father could not afford to pay for it. Finally, 28-year-old Muhammad Ikram was from Gujranwala and had matriculation-level education. He was single and his widowed mother, brother, and sister were dependent on him. His siblings were under 18 years of age.

\section{Work, Wages, Remittances, and Life during the Pandemic in Malaysia}

According to Sajid, he could somehow manage to send money to his family pre-COviD-19. As he did not possess a work permit, finding work during the pandemic was extremely difficult. His work was often for low wages, while some of the employers (i.e. "bosses" as per the workers) did not give any wages as they were aware of the lack of work permit. Furthermore, Sajid highlighted the fear rampant among all migrant workers of being caught by the police and immigration authorities during the pandemic.

Rehmat and Ayoub had the same concerns, whereby Ayoub further added that the issue of the lack of a work permit rendered him unable to find a well-paid job. The pandemic conditions led to employers taking advantage of the workers' fears about their undocumented status and paid very little. He noted that he was not alone; many migrant workers also had documentation-related issues. In particular, Sajid could send only PKR15,000 (9oUSD) to his family during the pandemic from March 2020, which was an extremely small amount for his family, which included his parents, brother, wife and children.

Like many other migrant workers, Rehmat was deprived of many months of wages by his employers and "robbed" of money he had saved and borrowed by agents for the expensive work permit. Without work permits, life for these migrant workers was full of risks, threats, exploitation, abuse and extreme stress. Rehmat said:

The majority of us [migrant workers] do not have a work permit. For some, they may have it, but many of those are fake work permits received via the under-the-table setting.

Besides, Rehmat reported that finding work was also tricky these days, rendering him unable to send money to his family. Starting from March 2020, when the first lockdown was imposed in Malaysia, up until the last eight months, Rehmat had sent only PKR50,000 (approximately 300USD) in total. This amount was almost nothing: 
We live in a rented house in Karachi. Therefore, it is a must that I should send some amount of money every month but I cannot; so, I have been borrowing from relatives in Pakistan.

Since 2014, Ikram had been in Malaysia. He first came on a visit visa but could not obtain a work permit following.

Back in 2018, Ikram had last paid RM9,ooo to a Chinese agent through six-month instalments, who was also the company owner, but could not obtain a work permit. Worst of all, his money was not refunded. Like thousands of other migrant workers, Ikram could not take any action against the agent and added:

In the current conditions in which I do not have work and a visa, I send very little money to my mother, brother and sister. They also feel sad and stressed because they receive little for their expenses.

Due to COVID-19, Ikram hardly got any work, while the occasions on which he was employed only resulted in minimal money. Pre-pandemic, he would often obtain work that paid around RM6 per hour, whereas he could barely earn RM4.50 per hour during the pandemic. Furthermore, he complained that overtime was not possible and the bosses often paid them very late. While he did not have any young siblings requiring milk, some of his fellow migrant workers had sold everything to pay the agents and come to Malaysia only to be denied a work permit. Thus, they were barred from proper and regular employment and could not send money regularly to their children even for education and food items.

Ahmed had earned good money and owned his house; as such, he did not need to pay rent and was sending a sufficient amount to his family. During the pandemic, he would send Rs5o,ooo (approximately 30ousD) to his wife; however, Ahmed was among the very few migrant workers who would receive regular work and adequate wages.

By contrast, Ahmed did not have a visa problem but he was not working in the same company for which he had a work permit. The police often asked Ahmed the reason behind his employment in another company despite his work permit for a different one, following which he would give them some minum (i.e. tea money). Besides, Ahmed noted that migrant workers also encountered severe difficulties in finding work during the COVID-19 pandemic, or otherwise paid extremely little. The combination of lacking work opportunities and little pay hindered them from sending money to their families, 
thus possibly skimping on the needs and basic rights of their children, such as education and welfare.

\section{$4 \quad$ Impact of the Pandemic on the Educational Rights of Migrant Workers' Children and Siblings}

The previous section delineated the severe effects of COviD-19 on the lives of Pakistani migrant workers in Malaysia, which caused the low flow of remittances for their families and children back in Pakistan. Subsequently, the basic educational rights of their children and siblings in their home country were compromised and affected. In Pakistan, free education is the right of every child from 5 to 16 years of age, a right set out in Article 25A of the Constitution of Pakistan (Mughal, 2020); and also under Article 28 of the UNCRC, which urges states to 'recognize the right of the child to education ... Make primary education compulsory and available free to all'. Pakistan ratified the UNCRC in November 199o, which makes Pakistan accountable to recognise, promote and protect the rights of all children including children whose parents are living in other countries for work or other purposes. The UNCRC also urges Pakistan to protect children from all kinds of harms and inhuman and degrading treatment in schools, homes and other places in Article 19. Article 18 (2) further requires states to assist families so that they can perform their child-rearing responsibilities. In addition, Article 24 of the UNCRC requires Pakistan to recognise and ensure that every child enjoys the highest attainable standards of health and provide them with facilities for the treatment and rehabilitation of health; and Article 27 recognises the right of children to a standard of living adequate for their physical, spiritual, mental, social and moral development (Nolan, 2019). However, the on-the-ground realities in Pakistan reflected in the narratives of the migrant workers are portrayed differently. Their children and siblings' rights to education, protection, play and others, especially in times of pandemic, are frequently denied.

To tackle the spread of the CoviD-19 pandemic, the provincial and federal governments had closed down all schools in mid-March 2020 (Latif and Sajid, 2020). The closure resulted in serious concerns among the respondents. However, they underlined additional concerns on top of said closure regarding the quality of education for their children due to their employment and financial conditions in Malaysia. For instance, Sajid's children attended a private school, which demanded monthly fees whether or not their attendance was fulfilled during the pandemic. Therefore, he was unable to send a sufficient 
amount as his remittances were only enough for routine or necessary spending required by his parents and wife. Meanwhile, he added:

I am worried about my children at all times, especially their education and protection. My two children go to school: my daughter is in the seventh grade, while my son is in fifth grade. In these [the pandemic] conditions, none of them goes to school. I have asked my wife not to send them and I always feel scared that they could contract the virus.

Furthermore, Sajid advised that schools in his district were often closed due to the pandemic, while they would be open for some of the time. According to him:

A few weeks ago, my daughter told me via a phone call [WhatsApp] that the headmistress repeatedly insulted her in front of her classmates for non-payment of monthly fees. When I heard about it, I felt very terrible and immediately borrowed some money from my co-workers to send it to my wife and pay five months' school fees amounting to Rs5,ooo.

The school administration's approach worked totally contrary to Sajid' daughter's right to inherent dignity and self-respect (as given in the preamble of the UNCRC). An alternative was for Sajid to take his daughter out of the school, but he could not afford that option as his village had only a private school catering to primary education. Meanwhile, his school-going brother went to a government school in an adjacent village for eighth-grade schooling, which was slightly farther from the village despite living with his family in Pakistan. Typically, his fellow villagers did not send girls to the government school as they would have to walk a long and dangerous hilly track. Therefore, education was not freely accessible to children in Sajid's village after completion of grade five. This is despite Article 25A of Pakistan's Constitution that guarantees free education for children aged between 5 to 16 years (Butt, 2019). Sajid added:

I fear that if these [CoviD-19] conditions persist for a long time, I will not be able to pay the fees for my daughter's schooling and she would be dropped from school. I want my daughter to become a doctor. The government did not do anything to the [management of] private schools about school fees.

Regarding Ayoub's two children, only his seven-year-old daughter attended school in the second grade of a government primary school. Due to the 
pandemic, he was concerned about his daughter's health first and then of her education. He said:

I am more worried that I am sending them extremely little money for their food and clothing. Allah willing, when these conditions are over, my daughter will continue her education; for now, the children should stay safe and protected.

Ahmed's children attended a private school. Ahmed reported that the children's schools in his area were closed for a few weeks due to the pandemic, resulting in his worry that his sons would miss one academic year. Nevertheless, he accepted his daughter's decision should she request to continue her education:

I do encourage her, but if she does not want to continue her education at any stage, I will not force her. However, I will force my sons to continue their education.

According to Ahmed, girls would eventually have to become housewives while the boys had to work; furthermore, the latter could get good jobs if they were given sufficient education. His perspectives regarding his sons' education preferences were unsurprising they reflected the most common practices observed in Pakistan in which female education is given less priority (Sudduth, 2009; $\mathrm{HRW}$, 2018). In the current conditions, girls' education would be a tough choice for many migrant workers upholding patriarchal social norms (see Khoso, 2020). This prioritisation reveals further discrimination against girls in education in contravention of Article 2 of the UNCRC read with Articles 28 and 29. This treatment also reveals that girl children were given lower status and that put their basic rights to development and survival at risk (Theytaz-Bergman, 1995). Due to discrimination at the state and communities level in Pakistan, the female literacy rate in Pakistan was 49 in 2018-2019, which is low as compared to the male literacy rate at 71 (Economic Survey of Pakistan, 2018-19).

Ikram was tasked with supporting his younger brother and sister in their education. Ikram's father died a couple of years ago, thus rendering him responsible for taking care of his siblings' needs and rights. Ikram stated:

I do not think of my sister's education. She is in eighth grade and the least interested in her education. I also do not push or encourage her and worry about her education because she would not need to do any job. These days, she stays with my mother and takes care of her needs because old people need help and support to stay away from the virus. However, I would often argue with my brother about his education. 
Besides, he could only send his family an extremely small amount of money, just sufficient for their needs:

I am not against girls' education, but my sister has enough of it. She will be married ultimately. In these conditions, in which we have little money, I would say that my brother should go to school and it would be better if my sister stays at home.

This statement highlights the fact that girls have fared worse in the pandemic and that there is a further, fundamental denial of the rights of girl children to non-discrimination in the enjoyment of their rights in the UNCRC.

However, Ahmed had a total of three brothers and one sister. Of these, his two brothers were over 18 years of age. Meanwhile, his youngest brother and sister were 15 and 13-years-old, respectively, but they did not go to school despite being within the range of school-going age as enshrined under $25 \mathrm{~A}$ of the Constitution of Pakistan. They ceased their schooling a few years ago as Ahmed's father could not afford to pay for their education due to poverty. Ahmed was not worried about his siblings' education, whereas his concern was directed to his three children and their education, who were eight, five, and three-years-old, respectively. According to Ahmed:

I am concerned about my children's education. These days, my sister often asks to re-join a school but I could hardly afford to support my own children's education. I have not answered my sister's request, but I do not think she needs to continue her education. She should help my mother as she is getting older and the pandemic is dangerous; she [mother] needs somebody with her at all times.

Meanwhile, Ahmed believed that private school administrators should take the necessary measures to continue children's education delivery. In Pakistan, schools were closed in March 2020 before they were re-opened in September and subsequently closed again in November of the same year. Students from first grade up until 12th grade were promoted to their subsequent grade without having to take an examination (The News International, 2020), which was a decision dismissive of their learning and did not occur during school closure. Besides, children from rural areas had no opportunity to learn through online learning systems utilised by the education departments (Geven and Hasan, 2020).

For Ahmed, the government's decision to allow children to enter the subsequent grades was good but his concern for their learning remained. However, 
he further confessed his inability to help with his children's homework due to not having an adequate education. He said:

But my children are always worried about the homework sent by their teachers on WhatsApp. My wife is not educated, only completing her primary schooling; thus, she could not help them. They would always complain that they could not do their homework and needed help.

Rehmat expressed similar worries about his children not getting an education as teachers in the current climate did not pay attention to the learning process and progress. According to him, schools were closed for many months; however, when they were reopened for two days a week, teachers were unable to teach and merely killed time by managing the children. Regardless, Rehmat's children were promoted to the next grades in July 2020, whereby they informed him via phone that they were promoted despite not completing the course. Rehmat stated:

My wife is just a primary school-level graduate like me and cannot help the children with their school work. When they converse with me via WhatsApp, they always complain that no one could help them; thus, I think they are not learning anything related to their course work.

The amalgamation of such conditions indicated that the children could not receive guidance and information related to their education as required by Article 28 (1)(c) of the United Nations Convention on the Rights of the Child (hereafter the CRC). The Article requires states to:

Make educational and vocational information and guidance available and accessible to all children. Children and Siblings

In general, migrant fathers and brothers function as the breadwinner but they also provide moral support, guidance, strategies and suggestions related to any issues and matters surfacing in their families or family members dependent on them. The impacts of the covid-19 pandemic on migrant children and siblings' needs and rights further underline the essential role played by these 
migrant men. For example, their children's lives and rights would be directly impacted in the setting of their home country, Pakistan, whereas the indirect effect can be observed from the lives of their fathers or brothers in the destination country (i.e. Malaysia).

In the case of Rehmat, he did not think as much about his family, especially his children, before the pandemic. In contrast, his worries about them during the pandemic were overwhelming as the children were not going to school and prohibited from playing with fellow neighbourhood children. He said, 'Life for the children was not the same as pre-pandemic. Therefore, they have become more demanding.'

Ayoub reported that previously in his absence, his wife and mother would often visit the market and bought clothes and toys for the children. However, over the last year, especially during the pandemic, they had ceased this routine as he could only send them a small amount of money. Meanwhile, Sajid's parents were poor, resulting in his responsibility to help his parents, brother and his own family. His concerns were more about the food, protection and clothes for his children as they had little money to buy rations during the pandemic. This indicates towards a lack of state social and security support as provided for in Article 26 of the CRC. However, Rehmat was not only feeling sorry about his inability to send adequate funds home but was sad, due to the loss of freedom experienced by his children: 'They mostly spent time at home playing and fighting with each other.'

Sajid often spoke with his daughter and encouraged her to spend more time reading and learning from the course books available, but she faced many issues in completing her school work as his wife was not educated; this was similar to the wives of the other four migrant workers in this research. Furthermore, subpar mobile signals in his village also caused difficulties in managing online-based education, which was only seemingly a formality. The teachers typically sent messages on the phone and talked for a few minutes with the students without resolving their issues. Besides, Sajid did not have enough funds to provide tuition classes for his daughter in the current conditions. He further added:

My children would always tell me [on the phone] that they did not have the money to buy toys, sweets and other things, whereas they often saw their friends having such things. They often showed their sad faces on WhatsApp and I would always tell them that these days would be over when the virus is gone. 
Moreover, Sajid shared that he could not send them enough money and thus noticed that his children often fought on petty issues, especially on toys. They were not permitted to go outside and play with their friends outside their homes. Sajid. He stated: 'I regularly speak with them and ask them to be happy and patient with things that are available for them. Before this, the children were not so irritated and annoyed.'

For Ayoub, talking with his children usually consisted of them asking for some money to buy sweets and toys. However, his wife had also started complaining recently about their irritation and frustration:

I would tell my wife to be patient, but she always said that she was unable to manage the children without spanking them. I have seen her become harsh on them [children] and she has started scolding and beating them. Therefore, I have to call and speak to her at least twice a day. Before this, I only talked [to them] on alternative days.

Similarly, Ahmed underlined that he had started noticing his children's disturbed and irritating behaviours after the pandemic started. He said:

Earlier, they would spend their time in school and parks playing with their friends, but now these activities could not be done. Therefore, I would spend more time with my sons on the phone.

The children's fights also caused some frustration and arguments between migrant fathers in Malaysia and their wives in Pakistan. For example, Ahmed sometimes scolded his wife for not handling them correctly, but he also came to realise that she was alone to carry out this task.

In the case of Ahmed, he also spent more time on the phone with his children and wife following the COVID-19 pandemic. As he was without any work for many months and his children did not go to school due to closure, they were free to converse longer, especially to his children who desperately missed their school and classmates. Therefore, Ahmed was able to understand the causes of stressful life faced by his children and wife, adding that: 'Sudden changes in their lives have caused unhappiness. They are fighting with each other at all times and have started shouting, which has never happened before.'

Ahmed's wife was his frequent informant regarding the activities and issues carried out and faced by their children. Therefore, Ahmed would often console his wife and gave his children hope by telling them that things would change soon, thus calling them every day and sometimes up to three times a day. $\mathrm{He}$ stated: 
Sometimes, I would scold my wife for not taking care of the children when they are deprived of their school life and could not play with their friends. She would just listen to me; I feel sorry to do this but I have to because she has become too addicted to her mobile device. She would continuously chat with her friends most of the time and not pay attention to the children's needs.

Meanwhile, Rehmat's wife and mother were scared of the Covid-19 virus and its consequences, while his children were not as they did not understand its consequences. As these younger children did not regularly attend school due to the pandemic, their freedom and social life were taken away. The long-term stay at home without any social activities caused psychological stress among them, resulting in him noticing their frequent fights with each other. They also kept complaining to their mother every time, who would then punish them.

Rehmat believed that she should not punish the children but it was a common practice in Pakistan; otherwise, it was thought that they would not demonstrate good behaviour. The country does not ban corporal punishment in homes, which affects children's right to safety, integration and protection (Holden and Ashraf, 2016). Besides, Rehmat indicated that:

I feel sad when they complain about their mother beating them. I tell my wife not to do so and she would always reply that I should come back to Pakistan to care for them instead as she cannot manage them alone. Therefore, I have to call her most of the time, as well as requesting for my mother to help her in taking care of the children.

Except for Ikram, all of the remaining respondents shared that their children spent time at home watching TV and playing games on their mother's mobile phones.

The Government of Pakistan (GoP) is responsible in ensuring that all children's rights, especially the rights of children whose parents have migrated to other countries for livelihood purposes, are fulfilled since they are equally entitled to special care and assistance in times of health emergencies, such as COVID-19, as given in the preamble of the CRC (also see Seddighi et al., 2021). Nevertheless, many topics and matters were reflected in the migrant workers' narratives, which revealed the severe impact of the Covid-19 pandemic on 
children and siblings' rights to education, health, protection and play. The GoP did not provide them with adequate required support that has been urged in the CRC and the CRC Committee's General Comments.

Migrant workers' children and siblings were not only impacted due to the conditions in the home country (i.e. Pakistan) but some of the adverse consequences were also attributable to those whose decisions affected them in the destination country (i.e. Malaysia) (please see Table 2 for the indirect impacts of the Covid-19 pandemic on children's rights). The destination countries often escape such responsibilities for the rights of migrant workers' children; and in cases where migrant workers are undocumented, as was the case with the majority of the research participants, they are arrested and deported only when they are provided with quick counsellor access and a return air ticket by their High Commission in Kuala Lumpur; otherwise, they are kept in immigration detention camps for many years.

Malaysia has not ratified the International Convention on the Protection of the Rights of All Migrant Workers and Members of Their Families (United Nations Human Rights Treaty Bodies, undated). Article 17 (6) states:

Whenever a migrant worker is deprived of his or her liberty, the competent authorities of the State concerned shall pay attention to the problems that may be posed for members of his or her family, in particular for spouses and minor children.

The miserable environment and exploitative conditions faced by migrant fathers and brothers throughout the CoviD-19 pandemic in the destination country has resulted in a reduced flow of remittances to their families and increased intensity of emotional and caring relationships with their children. Besides, the conditions encountered in the destination country and continuous demands for money by their children has increased the level of stress and anxiety for these migrant workers.

The reduced flow of remittances to their families and children has affected children's rights to education, livelihoods, food and other basic needs enshrined in the Constitution of Pakistan and the CRC. One of the prime concerns detailed by the migrant fathers was their children's education, especially among the sons (e.g. Ahmed). Besides the fear of losing one full year of education, the respondents were troubled regarding its quality and the lack of support and assistance extended to their children to attain quality education. Pakistan has yet successfully to handle the education of millions of its child population, whereby an estimated 30 per cent of those aged between 6 and 16 years in the rural areas are reportedly out of school (Mughal, 2020). 
TABLE 2 The indirect impacts of COVID-19 pandemic on the children and siblings of migrant workers

The indirect impacts of the COVID-19 pandemic on children's rights

$\downarrow$

$\downarrow$

Impacts on the behaviour displayed by Impacts on the flow of remittances migrant fathers and brothers towards their children and siblings in Pakistan

\begin{tabular}{|c|c|c|c|c|c|}
\hline $\begin{array}{l}\text { Fights and } \\
\text { arguments } \\
\text { between } \\
\text { spouses, } \\
\text { which } \\
\text { affected } \\
\text { family envi- } \\
\text { ronment (see } \\
\text { preamble of } \\
\text { the UNCRC) }\end{array}$ & $\begin{array}{l}\text { Little } \\
\text { priority } \\
\text { to female } \\
\text { education } \\
\text { (especially } \\
\text { siblings) } \\
\text { (Article 2) }\end{array}$ & $\begin{array}{l}\text { Consoling } \\
\text { Caring and } \\
\text { sparing more } \\
\text { time } \\
\text { The } \\
\text { frequency } \\
\text { and duration } \\
\text { of calls } \\
\text { increased }\end{array}$ & $\begin{array}{l}\text { Less flow for } \\
\text { children educa- } \\
\text { tion (i.e. fees) } \\
\text { (Article } 27 \text { of the } \\
\text { UNCRC makes the } \\
\text { state responsible } \\
\text { for ensuring the } \\
\text { financial needs of } \\
\text { children) }\end{array}$ & $\begin{array}{l}\text { Extremely } \\
\text { little for } \\
\text { sibling } \\
\text { education }\end{array}$ & $\begin{array}{l}\text { Extremely } \\
\text { little } \\
\text { flow for } \\
\text { children's } \\
\text { play items } \\
\text { (Article 31- } \\
\text { the right to } \\
\text { play) }\end{array}$ \\
\hline
\end{tabular}

Since the GoP expects billion of dollar remittances from the migrant workers (Salik, 2020), it has not been able to evolve a mechanism to support families and dependent children of migrant workers being impacted by emergencies or health crisis in the destination or home countries. Given Article 26 of the CRC, migrant workers' children and siblings with limited financial support should have been provided with adequate financial and social security support by the GoP, but this was not the case.

Furthermore, while Pakistan legally bans corporal punishment in schools, it is widely practised across the country (Global Initiative to End All Corporal Punishment of Children, 2020). The information obtained from migrant workers indicated children to be the frequent victims of harsh treatment and physical abuse from adult family members during the pandemic. The phenomenon has exacerbated their safety, protection, emotional integrity and physical health regardless of these practices being against Articles 19 and 37 (a) of the CRC. Article 37(a) states:

No child shall be subjected to torture or other cruel, inhuman, or degrading treatment or punishment (UNITED NATIONS, 1989). 
TABLE 3 The direct impacts of the COVID-19 pandemic on children and siblings' rights as reported by migrant fathers and brothers

The direct impacts of the COVID-19 pandemic on children's rights

\begin{tabular}{lllll}
\hline & $\downarrow$ & $\downarrow$ & $\downarrow$ & $\downarrow$ \\
\hline Loss of freedom to & Loss of & Increased irritation/ & Harsh & Loss of \\
move (i.e. go out- & social & stress and increased & treatment & learning and \\
side and play with & activities & fights and arguments & by mothers & quality of \\
fellow children) & (Article & among siblings & (Articles 29 & education \\
(Article 31 of the & 31 of the & (Articles 20 and 27, & and 37 of the (Article \\
UNCRC the right to & UNCRC) & congenial family & UNCRC & 28 of the \\
play) & & environment) & & UNCRC) \\
\hline
\end{tabular}

Although the COVID-19 pandemic affected the emotional life of Pakistani migrant workers in Malaysia, their harmful and discriminatory normative views in which preference was directed to the sons over daughters persisted. The narratives also revealed that migrant brothers were unconcerned about the education of their school-going-aged siblings. Even if their siblings were dependent on them, some depicted minimal concern for their education, especially for their sisters (please see Table 3 for the direct impacts of the COVID-19 pandemic children's rights).

Based on six interviews conducted with Pakistani migrant workers in Malaysia - five of whom were undocumented - this article found that the CoviD-19 pandemic had impacted on their children and dependent siblings' rights, including the right not to be discriminated against, the right to protection from abuse, the right to social security, the right to education and the right to play linked to Articles 2, 19, 26, 28 and 31 of the CRC respectively.

Migrant workers' vulnerability was amplified due to the pandemic, leading to unemployment, reduced working days and wages, social isolation and extreme psychological stress. Their vulnerabilities added to the vulnerabilities of their children and siblings. In particular, those with documentation-related issues faced severe challenges including extremely low or no wages, causing them to renegotiate the amount of their remittances sent to their family members, including children or siblings. Their families receive reduced remittances until normal circumstances are resumed, yielding less investment in children's education and little pocket money for them which directly impacts their right 
to education. Migrant workers also revealed the unhappy and stressful lives of their siblings and children, reporting an increase in violence at home.

Moreover, these workers' common, gendered normative views, upholding preferences for male education, were mostly unaffected by Covid-19, while indirectly impacting female well-being, rights and education as reflected in neglect (against Article 19 of the CRC) (United Nations, 1989). This shows that such harmful normative practices remain prevalent among migrant workers about their children and siblings (especially girls) during the pandemic. Such prerogative was reflected in the minimal concern shown by migrant workers for their siblings and daughters' education as opposed to the same for their sons.

The findings also highlight that during the pandemic, children were often victims of harsh treatment and physical abuse by adult family members, exacerbating their safety, protection, emotional integrity and physical health. This directly contrasts Articles 19 (1) and 37 (a) of the CRC in which children should never be subject to torture, or any form of inhuman and degrading treatment or punishment.

Given the state of Malaysia's migrant workers' children and siblings in Pakistan, the most obvious matter that surfaces is Pakistan's lack of realisation and understanding of legal duties arising from children's social and economic rights in times of emergencies and normal circumstances (see Byrne, 2020). Pakistan is duty bound to implement the CRC in all circumstances to ensure all rights of children, especially children whose parents and guardians are out of the country for work. In this context, special measures like social security (Article 26 of the CRC) and allocation of budgets are indispensable as directed in General Comment No. 19 on public budgeting for the realisation of children's rights (Art. 4) (CRC Committee, 2016). Furthermore, Pakistani children 'require bespoke protection' (Lundy, 2019), not only in normal times when they are developing and vulnerable to harms because of their size and lack of authority, but especially in emergencies when adult members of marginalised groups such as migrant workers are experiencing human rights abuses which then has a profound knock-on effect on their children.

\section{References}

Anderson, K. H., and Kroeger, A., "Remittances and Children's Capabilities: New Evidence from Kyrgystan, 2005-2008", CASE Network Studies and Analyses No. 430, DIW Berlin Discussion Paper No. 1170. 2011. http://dx.doi.org/10.2139/ssm.1950540. Azizi, S., "The impacts of workers' remittances on human capital and labour supply in developing countries", Economic Modelling 2018 (75), 377-396. 
Butt, A. I., "Ideational Leadership and Legislation: The Right to Free and Compulsory Education in Pakistan", in H. M. Grimm (eds.), Public Policy Research in the Global South: A Cross-Country Perspective. Doi.org/10.1007/978-3-03o-o6o61-9_15.

Byrne, S., "Reclaiming Progressive Realization: A Children's Rights Analysis", The International Journal of Children's Rights 2020 (28(4)), 748-777.

Cahapay, M. B., "How Filipino parents home educate their children with autism during COVID-19 period”, International Journal of Developmental Disabilities 2020. Doi.org/ 10.1080/20473869.2020.1780554.

Choudhari, R., "COVID 19 pandemic: mental health challenges of internal migrant workers of India”, Asian journal of psychiatry 2020 (54). Doi.org/10.1016/j. ajp.2020.102254

Coronel, F. K. and Unterreiner, F., "Increasing the Impact of Remittances on Children's Rights", Philippines paper, 2007, UNICEF: https://www.unicef.org/french/files/ Increasing_the_impact_of_remittances_on_childrens_rights.pdf.

CRC Committee, "General Comment No. 13: the right of the child to freedom from all forms of violence, UN Doc.", 2011, CRC/C/GC/13: https://www2.ohchr.org/english/ bodies/crc/docs/CRC.C.GC.13_en.pdf.

CRC Committee, "General comment No. 19: public budgeting for the realization of children's rights (Art. 4), UN Doc., 2016, CRC/C/GC/19: https://undocs.org/en/ CRC/C/GC/19.

Economic Survey of Pakistan, 2018-19, "Chapter 10: Education": http://www.finance. gov.pk/survey/chapter_2o/10_Education.pdf.

Geven, K. and Hasan, A., "Learning Losses in Pakistan Due to COVID-19 School Closures: A Technical Note on Simulation Results", (2020): http://hdl.handle.net/10986/34659 Global Initiative to End All Corporal Punishment of Children, "Corporal Punishment of children in Pakistan”, 2020: http://www.endcorporalpunishment.org/wp-content/ uploads/country-reports/Pakistan.pdf.

Holden, G. W. and Ashraf, R., "Children's right to safety: The problem of corporal punishment in Pakistan”, in S. Deb (eds.), Child safety, welfare and well-being (New Delhi: Springer, 2016).

Honorati, M., Yi, S. and Choi, T., "Assessing the Vulnerability of Armenian Temporary Labor Migrants during the Covid-19 Pandemic", Social Protection and Jobs Discussion Paper No. 2003 (World Bank, 2020): https://openknowledge.worldbank. org/handle/1og86/34359.

HRw, “Shall I Feed My Daughter, or Educate Her?' Barriers to Girls' Education in Pakistan", 2018: https://www.hrw.org/report/2018/11/12/shall-i-feed-my-daughteror-educate-her/barriers-girls-education-pakistan.

Karim, M. R., Islam, M. T. and Talukder, B., “COvID-19' s impacts on migrant workers from Bangladesh: In search of policy intervention", World Development, 2020: Doi. org/10.1016/j.worlddev.2020.105123. 
Khoso, A., "Pakistani Male Migrant Workers' Social Practices in Kuala Lumpur Malaysia: Understanding Agency and Structure", PhD Thesis. Faculty of Arts and Social Sciences, University of Malaya.

Khoso, A., Thambiah, S. and Hussin, H., "Social practices of Pakistani migrant workers in Malaysia: Conserving and transforming transnational affect", Emotion, Space and Society 2020: Doi.org/10.1016/j.emospa.2020.100742.

Latif, A. and Sajid, I., "Pakistan closes schools, universities over coronavirus", 2020: https://www.aa.com.tr/en/asia-pacific/pakistan-closes-schools-universities-overcoronavirus $/ 1765276$.

Lee, Y. N., "Neglect of migrant workers could hurt Malaysia's economic recovery", 2O2O: https://www.cnbc.com/2020/11/05/covid-19-migrant-worker-neglect-may-hurtmalaysia-economic-recovery.html.

Lundy, L., "A Lexicon for Research on International Children's Rights in Troubled Times", The International Journal of Children's Rights 2019 (27(4)) 595-601.

Mughal, A. W., "Secondary school students who drop out of school in rural Pakistan: The perspectives of fathers", Educational Research 2020 (62(2)), 199-215.

Mukumbang, F. C., Ambe, A. N. and Adebiyi, B. O., "Unspoken inequality: how COVID-19 has exacerbated existing vulnerabilities of asylum-seekers, refugees, and undocumented migrants in South Africa", International journal for equity in health $2020(19(1)), 1-7$.

Nolan, A. "Article 27 - The Right to an Adequate Standard of Living", in J. Tobin (eds.), The Convention on the Rights of the Child: A Commentary (Oxford: Oxford University Press, 2019).

Parreñas, R. S., "Mothering from a distance: Emotions, gender, and intergenerational relations in Filipino transnational families", Feminist studies 2001 (27(2), 361-39o.

Raman, S., Harries, M., Nathawad, R., Kyeremateng, R., Seth, R. and Lonne, B., "Where do we go from here? A child rights-based response to COVID-19", BMJ paediatrics open 202O, (4(1)): 10.1136/bmjpo-202O-0oo714.

Salik, K. M., "Policy Review Remittances and coviD-19: Is Pakistan ready for a likely decline in flows?", Sustainable Development Policy Institute, 2020, 1-8.

Seddighi, H., Salmani, I., Javadi, M. H. and Seddighi, S., "Child abuse in natural disasters and conflicts: a systematic review", Trauma, Violence \& Abuse 2021 (22(1)), 176-185.

Silverman, M., Sibbald, R. and Stranges, S., "Ethics of coviD-19-related school closures", Canadian Journal of Public Health 2020 (111(4)), 462-465.

Sudduth, J. T., "CEDAW's Flaws: A Critical Analysis of Why CE DAW is Failing to Protect a Woman's Right to Education in Pakistan",Journal of Law and Education 2009 (38(4)), 563-592.

Suresh, R., James, J. and RSj, B., "Migrant Workers at Crossroads - The Covid-19 Pandemic and the Migrant Experience in India", Social Work in Public Health 2020 $(35(7)), 633-643$. 
Takenaka, A. K., Gaspar, R., Villafuerte, J. and Narayanan, B., "CoviD-19 Impact on International Migration, Remittances, and Recipient Households in Developing Asia", Asian Development Bank 2020: http://hdl.handle.net/11540/12258.

The News International, "Students of grades I to XII to be promoted without taking exams" 2020: https://www.thenews.com.pk/print/666o23-students-of-grades-i-toxii-to-be-promoted-without-taking-exams.

Theytaz-Bergman, L., "Committee on the Rights of the Child: Eighth Session Day of General Discussion on the girl child", The International Journal of Children's Rights $1995(3(2)), 270-271$.

United Nations, "Convention on the Rights of the Child", 1989: https://www.ohchr.org/ EN/ProfessionalInterest/Pages/CRC.aspx.

United Nations Human Rights Treaty Bodies, "UN Treaty Body Database: Ratification Status for Malaysia": https://tbinternet.ohchr.org/_layouts/15/TreatyBodyExternal/ Treaty.aspx?CountryID=105\&Lang=EN.

Wang, G., Zhang, Y., Zhao, J., Zhang, J. and Jiang, F., "Mitigate the effects of home confinement on children during the CoviD-19 outbreak", The Lancet 2020 (95), 945-947: https://doi.org/10.1016/So140-6736(20)30547-X.

Wise, A. and Velayutham, S., "Transnational affect and emotion in migration research", International Journal of Sociology 2017 (47(2)), 116-130. 